\title{
Al-Chizan
}

Jurnal Pemikiran Hukum Islam

ISSN 1907-0985, E ISSN 2442-8256

Vol. 13, No. 2, 2017, h. 140-155

DOI: https://doi.org/10.30603/am.v13i2.855

\section{Integrative Approach in Enforcing Sharia Islam in South Sulawesi}

\author{
Ahmad Faisal \\ IAIN Sultan Amai Gorontalo \\ Email: ahmadfaisal@iaingorontalo.ac.id
}

Abstract: This article aims to explain the plus and minus approach in perpetuation of sharia Islam in South Sulawesi. Substantial and cultural approacheswhich emphasis on the ethical aspects as well as the formalistic legalistic structural approach, both have weaknesses. This study found out that formalist Islamic movement, with its choice of structural paths, proved to not fully succeed in realizing the ideals of perpetuation sharia Islam. On the contrary, even cultural Islam has not fully succeeded in realizing the ideals of religion in its comprehensive understanding. By looking at the socio-political reasons above, it is very argumentative if the two contraditory the approaches have been positioned dichotomically integrated. Moreover, in historical-empirical experiences in South Sulawesi, both approaches have been implemented with varying degrees of results.

Keywords: Integrative Approach, Islamic Law, South Sulawesi

\section{Pendekatan Integratif dalam Penegakan Syariat Islam di Sulawesi Selatan}

Abstrak: Artikel ini menjelaskan plus minus pendekatan dalam penegakan syariat Islam di Sulawesi Selatan. Baik pendekatan kultural yang substansialistik dan lebih menekankan aspek etik maupun pendekatan struktural yang bersifat legalistik formalistik, sama-sama memiliki kelemahan. Hasil studi ini menunjukkan bahwa gerakan Islam formalis, dengan pilihan pada jalur struktural, terbukti tidak sepenuhnya berhasil merealisasikan cita-cita penegakan syariat Islam. Sebaliknya, Islam kultural pun, belum sepenuhnya berhasil mewujudkan cita-cita agama dalam pengertiannya yang konfrehensif. Dengan melihat alasan sosio-politis di atas, maka sangat argumentatif jika kedua kutub pendekatan yang selama ini diposisikan secara dikotomis, diintegralkan. Lebih dari itu, dalam pengalaman historis-empiris di Sulawesi Selatan, kedua pendekatan tersebut pernah diimplementasikan dengan derajat hasil yang berbeda-beda.

Kata Kunci: Pendekatan Integratif, Syariat Islam, Sulawesi Selatan 
Pendekatan Integratif dalam Penegakan Syariat Islam di Sulawesi Selatan

\section{A. Pendahuluan}

Keinginan untuk menegakkan syariat Islam di Indonesia, baik melalui jalur politik dan konstitusi yang legal, maupun melalui perjuangan fisik dengan menentang pemerintah yang sah, telah menjadi bagian dari sejarah panjang perjuangan umat Islam di Indonesia. ${ }^{1}$ Namun demikian, kenyataan sosial dan politik menunjukkan bahwa gagasan semacam itu tidak pernah mendapat dukungan mayoritas penduduk. Fenomena ini oleh banyak pengamat dianggap aneh, sebab Indonesia dikenal sebagai negeri dengan penganut Islam terbesar di dunia.

Seiring dengan itu, harus diakui pula bahwa bentuk pemikiran dan praktik yang dikembangkan oleh para pemikir dan aktivis pendukung gagasan penegakan syariat Islam selalu kental dengan nuansa legalistik dan formalistik. Antara lain karena alasan ini, gagasan tersebut tidak mendapat respons yang memadai. Piagam Jakarta yang mengandung klausul "keharusan untuk menjalankan syari'at Islam bagi para pemeluknya" disepakati untuk dianulir hanya sehari setelah kemerdekaan Indonesia diproklamasikan. $^{2}$

Pada masa-masa awal pemerintah Orde Baru berkuasa, peluang untuk menegakkan syariat Islam oleh para pendukungnya sepertinya sudah tertutup. Adanya stigma politis dan ideologis antara Islam dan negara pada masa-masa sebelumnya, sepertinya masih membekas. Bahkan, pada masa Orde Barulah sebenarnya implikasi-implikasi negatif dari preferensi politik generasi pemikir dan aktivis pertama menampakkan bentuknya. Dalam hal ini, untuk waktu yang cukup lama, perjuangan umat Islam yang dianggap tidak sejalan dengan arus utama politik Orde Baru dipinggirkan dan dibatasi.

${ }^{1}$ Deskripsi yang saling melengkapi mengenai hal itu dapat dibaca misalnya dalam Ahmad Syafi'i Maarif: Islam dan Masalah Kenegaraan: Studi tentang Percaturan dalam Konstituante (Jakarta: LP3ES, 1985); B.J. Boland, The Struggle of Islam in Modern Indonesia (The Hague: Martinus Nijhoff, 1971); Bahtiar Effendy, Islam dan Negara: Transformasi Pemikiran dan Praktik Politik Islam di Indonesia (Jakarta: Paramadina, 1998); Deliar Noer, Partai Islam di Pentas Nasional 1945-1965 (Jakarta: Pustaka Utama Graffiti, 1987), dan lain-lain.

${ }^{2}$ Deskripsi yang saling melengkapi tentang hal itu, dapat dibaca misalnya dalam Ahmad Syafii Maarif, Islam dan Masalah Kenegaraan: Studi tentang Percaturan dalam Konstituante (Jakarta: LP3ES, 1985); Endang Saefuddin Anshari, The Jakarta Charter1945: The Struggle for an Islamic Constitution in Indonesia (Kualalumpur: Muslim Youth Movement of Malaysia, 1979). 


\section{Ahmad Faisal}

Demikian jeleknya hubungan antara pemerintah dan Islam, sehingga dalam pandangan Muhammad Natsir, yang pertama (pemerintah) telah memperlakukan yang kedua (Islam) -seperti dituturkan kembali oleh Mohammad Kamal Hasan- bagaikan "kucing kurap."3 Situasi yang tidak mengenakkan itu berlangsung hingga tahun 1984.

Sejak 1985 sampai berakhirnya kekuasaan Orde Baru pada 1998, hubungan antara negara dan Islam menunjukkan suasana yang oleh banyak pengamat diklaim semakin mesra. Dalam suasana hubungan seperti itu pula, negara tampak semakin akomodatif terhadap berbagai kepentingan umat Islam. Pada era reformasi, hubungan baik tersebut terus berlanjut, bahkan masa-masa awal reformasi itu seringkali diistilahkan sebagai masa bulan madu antara Islam dan negara. Dalam pola hubungan itu, negara mengakomodasi aspirasi dan tuntutan umat Islam dalam skala yang lebih meningkat dibanding periode sebelumnya.

Jatuhnya rezim Orde Baru pada 21 Mei 1998 itu, sepertinya memberi peluang kembali bagi munculnya gagasan lama, seperti yang pernah dikembangkan pada dekade 1940-an hingga 1960-an. Karena itulah, dalam proses amandemen UUD 1945 yang mulai dilakukan dalam Sidang Umum MPR 1999 dan Sidang Tahunan MPR 2000 misalnya, kembali terjadi tarik menarik yang sangat kuat antara kelompok yang menginginkan diberlakukannya kembali Piagam Jakarta dengan kelompok lain yang mempunyai pandangan yang berbeda. ${ }^{4}$ Di masyarakat pun, tuntutan untuk menegakkan syariat Islam secara formal mulai disuarakan oleh beberapa kelompok umat Islam $^{5}$ di berbagai daerah. ${ }^{6}$

${ }^{3}$ Muhammad Kamal Hassan, "Muslim Intelectual Responsses to "New Order" Modernization in Indonesia,"sebagaimana dikutip Bahtiar Effendy dalam Teologi Baru Politik Islam: Pertautan Agama, Negara dan Demokrasi (Cet. I; Yogyakarta: Galang Press, 2001), 46.

${ }^{4}$ Wacana dan keinginan menghidupkan kembali Piagam Jakarta pernah muncul dan ramai diperjuangkan oleh politisi Muslim sebelum dan saat berlangsungnya sidang Umum MPR 1999 dan Sidang Tahunan 2000. Beberapa partai Islam yang getol memperjuangkan hal itu adalah Partai Persatuan Pembangunan (PPP), Partai Keadilan (PK), Partai Bulan Bintang (PBB), Partai Daulat Ummat (PDU), Partai Umat Islam (PUI), dan Partai Kebangkitan Ummat (PKU).

${ }^{5}$ Sekadar menyebut contoh, diantara kelompok yang menginginkan penegakan syariat Islam adalah Majelis Mujahidin Indonesia (MMI), Forum Komunikasi Ahlussunnah Waljamaah, Front Pembela Islam (FPI), Komite Indonesia untuk Solidaritas Dunia Islam (KISDI), dan lain-lain. 
Pendekatan Integratif dalam Penegakan Syariat Islam di Sulawesi Selatan

Di Sulawesi Selatan, gagasan itu digulirkan oleh Komite Persiapan Penegakan Syariat Islam (KPPSI). Sebagai daerah yang dikenal dengan penganut Islam yang fanatik, munculnya gagasan seperti itu di daerah ini tidaklah begitu mengejutkan. Apalagi dalam kenyataannya, KPPSI bukanlah kelompok yang pertama kali menyuarakan ide seperti itu di daerah ini. Sebelumnya, telah muncul gerakan DI/TII yang juga mengusung jargon perjuangan untuk menegakkan syariat Islam.

Bagi proponen pendukung KPPSI, secara historis Islam sejak dulu sudah menjadi agama anutan para raja dan rakyatnya di daerah ini, menjadi dasar orientasi dan way of life. Karena itulah Sulawesi Selatan kemudian digelari "Serambi Madinah". ${ }^{7}$ Secara sosiologis, kenyataan bahwa mayoritas penduduk Sulawesi Selatan adalah Muslim, merupakan alasan yang kuat untuk menopang gagasan itu. Kenyataan bahwa sistem hukum yang diberlakukan selama ini terbukti tidak efektif dalam menyelesaikan problematika umat, bagi para pendukung KPPSI dijadikan alasan filosofis untuk menguatkan gagasannya.

\section{B. Pendekatan Struktur Dalam Penegakan Syariat Islam Di Sulawesi Selatan}

Munculnya ide penegakan syariat Islam di Sulawesi Selatan seperti yang diperjuangkan oleh KPPSI pada orde reformasi ini, sebenarnya bukanlah sesuatu yang benar-benar baru dalam masyarakat Muslim di daerah ini. Ide seperti itu, sebelumnya pernah pula diperjuangkan oleh sekelompok

${ }^{6}$ Daerah-daerah lain yang juga dikenal dengan gagasan penegakan syariat Islamnya adalah Banten, Pamekasan, Sumenep, Gresik, Malang, Garut, dan Cianjur.

${ }^{7}$ Menurut Ahmad M. Sewang (sejarawan Muslim Sulawesi Selatan), istilah Serambi Madinah pertama kali dikenal pasca peristiwa G-30 S/PKI ketika suasana kehidupan umat waktu itu diliputi oleh rasa ketakutan dicap oleh pemerintah sebagai antekantek PKI. Diantara upaya untuk membebaskan diri dari kecurigaan tersebut, maka umat Islam di daerah ini kemudian menjadikan kedekatan terhadap aspek keagamaan sebagai pilihan karena secara praktis bertentangan dengan ajaran PKI yang atheis. Tetapi dalam perkembangan kemudian, beberapa kalangan mengusulkan agar pilihan itu diasosiasikan dengan nama Serambi Madinah sebagai imbangan terhadap gelar yang diberikan kepada Aceh dengan Serambi Mekkah-nya. Wawancara penulis dengan Ahmad M. Sewang, Makassar, 17 Mei 2003. Meskipun demikian, bagi sebagian orang istilah tersebut masih belum populer dan karena itu masih perlu pengkajian lebih mendalam, apalagi kalau kemudian dijadikan sebagai salah satu pijakan dalam menuntut pemberlakuan syariat Islam di daerah ini seperti halnya di Aceh. Wawancara penulis dengan Minhajuddin (tokoh agama Islam), Makassar, 18 Mei 2003. 


\section{Ahmad Faisal}

umat Islam di daerah ini pada masa Orde Lama yang menamakan diri sebagai kelompok Darul Islam/Tentara Islam Indonesia (DI/TII). ${ }^{8}$ Meskipun nuansa pemikiran dan orientasi perjuangannya sedemikian rupa berbeda dengan apa yang sekarang diperjuangkan oleh aktor pendukung KPPSI, kemunculan gerakan DI/TII itu sebelumnya tetap saja menarik untuk dikemukakan.

Dalam sejarah Sulawesi Selatan, munculnya Gerakan Darul Islam/Tentara Islam Indonesia (DI-TII) pada era 1950-an itu dipimpin oleh Abdul Qahhar Mudzakkar. ${ }^{9}$ Gerakan yang berlangsung dari tahun 1950-1965 tersebut, meskipun dalam kenyataannya sering dianggap hanya sebagai bentuk kekecewaan sekelompok tentara yang aspirasinya kurang diperhatikan pemerintah pusat ketika itu, ${ }^{10}$ namun dalam kenyataannya, isu yang diusung kala itu juga berorientasi pada upaya penegakan syariat Islam di Sulawesi Selatan dengan jalan membentuk wilayah demarkasi yang di

\footnotetext{
${ }^{8}$ Meskipun sejarah memberitakan bahwa sejak zaman kerajaan di daerah ini telah diberlakukan syariat Islam, maka jika pada bagian ini secara khusus dibatasi penelusurannya pada masa DI/TII saja, maka hal itu tidak dimaksudkan untuk memenggal peristiwa sejarah tersebut. Tetapi semata-mata dimaksudkan untuk mencari penjelasan yang memadai terhadap tudingan-tudingan yang mengemuka di masyarakat bahwa kemunculan KPPSI tersebut merupakan bentuk baru dari perjuangan DI/TII. Asumsi masyarakat tersebut terutama dibangun dari kenyataan bahwasanya dalam berbagai kegiatan yang dilakukan KPPSI, banyak dihadiri oleh tokoh-tokoh tua eks DI/TII dan keluarganya, apalagi dengan terpilihnya Asiz Qahhar (putra bungsu Qahhar Mudzakkar) sebagai Ketua Lajnah Tanfidziyah KPPSI.

${ }^{9}$ Penulisan nama Qahhar Mudzakkar sering dijumpai dalam banyak versi. Terkadang ditulis dengan Kahar Muzakkar, Kahar Mudzakkar, Qahar Muzakkar, Kahar Mudzakkir dan lain-lain. Tetapi berdasarkan pengakuannya sendiri, yang sebenarnya adalah Abdul Qahhar Mudzakkar. Dijelaskannya secara rinci; Abdul artinya Hamba, Qahhar berarti yang gagah perkasa, Mudzakkar artinya jantan. Jadi Abdul Qahhar Mudzakkar berarti hamba Tuhan yang bersifat jantan. Lihat Abdul Qahhar Mudzakkar, Tjatatan Bathin Pedjoang Islam Revolusioner, Jilid III (Singapura: Qalam Press, 1382 H), 113. Penulisan nama Qahhar Mudzakkar harus dilakukan dengan cermat, karena ada sementara penulis yang mempersamakannya dengan Kiyai Haji Abdul Kahar Mudzakkir. Misalnya dikatakan: "Terutama Ki Bagus Hadikusumo dan Kahar Muzakkir (yang kelak menjadi pemimpin teroris Darul Islam Sulawesi Selatan). Untuk ini lihat Pipitseputra, Beberapa Aspek dari Sejarah Indonesia Aliran Nasionalis, Islam, Katolik sampai Akhir Zaman Perbedaan Paham (Ende-Flores: Nusa Indah, 1973), 304. Pernyataan Pipitseputra itu jelas keliru, karena Abdul Kahar Muzakkir adalah tokoh penandatangan Piagam Djakarta yang tidak pernah memberontak.

${ }^{10}$ Anhar Gonggong, Abdul Qahhar Mudzakkar: Dari Patriot Hingga Pemberontak (Jakarta: Gramedia Widiasarana Indonesia, 1992), 94-97.
} 
Pendekatan Integratif dalam Penegakan Syariat Islam di Sulawesi Selatan

dalamnya diberlakukan syariat Islam sebagai pijakan dalam pengambilan keputusan, sesuai dengan konsep dan pemahaman mereka terhadap syariat itu sendiri.

Jika memperhatikan proses perkembangan gerakan Qahar Mudzakkar, maka tampak ada dua tahap untuk menjadikan Islam sebagai ideologi gerakannya. Tahap pertama, dari tahun 1950-1953 yang oleh Abdul Qahhar Mudzakkar disebutnya sebagai masa penggalangan dan masa peralihan; ${ }^{11}$ dan tahap kedua dari tahun 1953-1965 yang diistilahkan sendiri oleh Qahhar Mudzakkar dengan Revolusi Islam. ${ }^{12}$

Dalam pandangan Qahhar, masyarakat telah mengalami kerusakan yang diistilahkannya dengan telah "tjentang perenang". 13 Golongan masyarakat dunia kala itu, seperti liberalisme, komunisme gadungan dan golongan dunia agama (di luar agama Islam) dianggapnya sebagai faktorfaktor yang merusak masyarakat dunia. ${ }^{14}$

Setelah memberikan analisanya seperti itu, Qahhar menyebutkan bahwa hanya Islamlah yang dapat memperbaiki situasi masyarakat dunia. ${ }^{15}$ Berdasarkan pendapatnya itu, ia menjadikan ajaran Islam sebagai landasan gerakannya, dan tidak hanya dimaksudkan untuk bangsa Indonesia, melainkan juga untuk perdamaian dunia. Di dalam suratnya kepada Presiden Sukarno, dinyatakan bahwa usaha memperjuangkan perdamaian dunia tanpa kekuatan moral dan tanpa ajaran agama, adalah sia-sia. ${ }^{16}$ Karena itu, dalam tafsiran Qahhar Mudzakkar, baik liberalisme yang kapitalis maupun komunisme yang dipaksakan tidak mungkin dapat menyelamatkan masyarakat dunia. 17

${ }^{11}$ Qahhar Mudzakkar, Tjatatan Bathin, jilid I, 11.

${ }^{12}$ Qahhar Mudzakkar, Tjatatan Bathin, jilid I, 11.

${ }^{13}$ Istilah yang dimaksudkannya untuk menggambarkan situasi masyarakat dunia yang sedang dilanda krisis kekacauan kala itu dipergunakan Qahhar dalam berbagai tulisannya. Lihat misalnya buku karangannya yang lain, Revolusi Ketatanegaraan Indonesia Menudju Persaudaraan Manusia (Makassar: Hasanuddin University Press, 1381 H), 21; Lihat pula Qahhar Mudzakkar, Tjatatan Bathin, jilid III, 11, dan lain-lain.

${ }^{14}$ Uraian tentang penggolongan masyarakat dunia seperti yang dimaksudkannya diatas, lihat Qahhar Mudzakkar, Tjatatan Bathin, jilid III, 11, 11-41.

${ }^{15}$ Qahhar Mudzakkar, Tjatatan Bathin, jilid I, 39.

${ }^{16}$ Abdul Qahhar Mudzakkar, Revolusi, 26.

${ }^{17}$ Abdul Qahhar Mudzakkar, Revolusi, 74. 


\section{Ahmad Faisal}

Dalam tafsirannya, persoalan dunia yang dihadapi dewasa ini bukanlah gerak majunya sosialisme-komunisme menggantikan kapitalismeliberalisme, melainkan pertumbuhan semangat persaudaraan manusia dalam bentuk tuntutan menentukan nasib sendiri.

Berangkat dari alur pemikiran seperti itu, Abdul Qahhar Mudzakkar menganjurkan apa yang disebutnya Ichwatunisme, yaitu istilah yang berasal dari QS. al-Hujurat ayat 10 yang berbunyi: Innamal Mu'minuna Ichwatun... artinya: sesungguhnya orang-orang jang beriman kepada Tuhan adalah "Bersaudara." Ajaran yang dianjurkannya itu, menurut Qahhar merupakan roh kebangsaan Islam yang telah dilalaikan oleh para alim ulama dan pemimpin-pemimpin dunia Islam. Hal itu menyebabkan golongan umat Islam di seluruh dunia menjadi lumpuh. ${ }^{18}$

Atas dasar keyakinan seperti itu, Abdul Qahhar Mudzakkar mengajak Presiden Sukarno untuk menjadi penganjur perdamaian dunia yang berdasarkan ajaran Islam itu. Ajakan itu disampaikannya dalam salah satu suratnya:

Bung Karno jang saja muliakan!

Alangkah bahagia dan agungnja Bangsa Kita di bawah Pimpinan Bung Karno djika sekarang dan sekarang djuga Bung Karno sebagai pemimpin Besar Islam, pemimpin Besar Bangsa Indonesia, tampil ke muka menjeru Masjarakat dunia jang sedang dipertakuti Perang DuniaIII, dipertakuti kekuasaan-Nuklir, kembali ke djalan damai dan perdamaian jang ditundjukkan oleh Tuhan dalam segala AdjaranNja jang ada di dalam Kitab Sutji al-Qur'an dan dalam Kitab Sutji Agama lainnja. ${ }^{19}$

Setelah mengajak Presiden Sukarno untuk tampil sebagai tokoh dunia yang menyeru perdamaian sesuai ajaran Islam itu, Abdul Qahhar Mudzakkar menunjukkan jalan. Menurutnya, jalan yang sangat mudah itu adalah "mendecreetkan menggantikan Pantjasila dengan Falsafah Ketuhanan." ${ }^{20}$ Bunyi lengkap dari dekrit yang diusulkan Qahhar kepada Sukarno melalui suratnya itu ialah menggantikan Pancasila dengan: Adjaran

\footnotetext{
${ }^{18}$ Abdul Qahhar Mudzakkar, Revolusi, 76

${ }^{19}$ Abdul Qahhar Mudzakkar, Revolusi, 25.

${ }^{20}$ Abdul Qahhar Mudzakkar, Revolusi, 25.
} 
Pendekatan Integratif dalam Penegakan Syariat Islam di Sulawesi Selatan

Islam dan Adjaran Agama lainnja jang dianut oleh segenap Suku bangsa Indonesia." 21

Karena penerimaan dan keyakinannya yang kuat terhadap kebenaran Islam itulah, maka selama memimpin gerakan Darul Islam/Tentara Islam Indonesia di wilayah Sulawesi Selatan, Qahhar Mudzakkar memberlakukan hukum-hukum syariat secara total sesuai pemahamannya dan dalam bentuknya yang literal.

Selama diberlakukannya syariat Islam ketika itu, maka tingkat kejahatan dan kemaksiatan di masyarakat memang dapat diminimalisasi, seperti diungkapkan secara eksplisit oleh Ja'far Sanusi. Secara panjang lebar, tokoh ulama yang sekarang menjabat Ketua Majelis Ulama di salah satu kabupaten di Sulawesi Selatan itu membandingkan tingkat kemaksiatan dan kriminalitas yang terjadi di masyarakat ketika syariat Islam diberlakukan dan tidak. ${ }^{22}$

Meskipun sangat mungkin ketika gerakan DI/TII itu berkuasa, tingkat kejahatan yang dilakukan oleh anggota masyarakat dapat diminimalisasi, tetapi terdapat fenomena lain yang justru sangat paradoks dengan argumen Ja'far tersebut. Seperti dikemukakan oleh Anhar Gonggong, pada masa DI/TII itu pulalah terjadi berbagai bentuk kejahatan, baik terhadap jiwa maupun harta benda yang dilakukan oleh pengikut gerakan DI/TII. ${ }^{23}$ Kejahatan terhadap jiwa terutama dilakukan terhadap mereka yang secara terang-terangan menunjukkan sikap tidak loyal terhadap gerakan itu, sementara kejahatan dalam bentuk perampokan, pencurian dan sejenisnya dilakukan sebagai upaya untuk mengamankan pasokan pangan demi kelangsungan perjuangan.

Jika perilaku-perilaku menyimpang tersebut dihubungkan dengan misi perjuangan yang mereka gembar-gemborkan yakni perjuangan demi tegaknya sebuah negara Islam yang di dalamnya syariat Islam diterapkan, maka dengan alasan yang mudah dimengerti, gerakan semacam itu tidak akan mendapatkan simpati dan dukungan. Memang masyarakat Sulawesi Selatan ketika itu, terpola dalam kelompok-kelompok yang pro dan kontra. Mereka yang pro umumnya adalah kelompok masyarakat yang merasa mendapatkan keuntungan dengan adanya gerakan itu, baik secara langsung

\footnotetext{
${ }^{21}$ Abdul Qahhar Mudzakkar, Revolusi, 25.

${ }^{22}$ Ja'far Sanusi, Tokoh Agama/Ulama, Wawancara, di Pinrang, 2 Juli 2003.

${ }^{23}$ Anhar Gonggong, Abdul Qahhar Mudzakkar, 57.
} 


\section{Ahmad Faisal}

maupun tidak. Akan tetapi, mayoritas penduduk tetap saja menganggap gerakan itu hanya sebagai gerakan sempalan, yang berjuang demi dan atau atas nama Islam bukan karena kesadaran ideologis semata, tetapi lebih karena faktor sosial politik.

Oleh karena itu pulalah, maka ketika gerakan itu berhasil dilumpuhkan oleh TNI pada tahun 1965, masyarakat Sulawesi Selatan menyambutnya dengan suka cita, dan bahkan selama proses penumpasan gerakan itu, tidak kurang bantuan yang diberikan penduduk bagi TNI demi mempercepat upaya penumpasannya. ${ }^{24}$

Fenomena keterlibatan masyarakat tersebut jika ditafsirkan akan berarti bahwa isu penegakan syariat Islam yang digulirkan oleh DI/TII ketika itu tidak mendapat simpati dan dukungan masyarakat, meskipun kenyataan menunjukkan bahwa mayoritas masyarakat Sulawesi Selatan ketika itu adalah kelompok Muslim yang masih tradisional, dalam pengertiannya yang paling umum.

Pandangan seperti itu benar adanya, terutama jika dikaitkan dengan penerimaan masyarakat Muslim di daerah ini terhadap tokoh-tokoh Islam masa lalu. Terhadap ketokohan Abdul Qahhar Mudzakkar misalnya, yang pernah memunculkan ide negara Islam lewat gerakan DI/TII-nya, untuk konteks kekinian hanya mendapat simpati sangat terbatas pada daerahdaerah tertentu saja, terutama daerah Luwu yang memang menjadi basis sosio-kultural tokoh itu. Sementara di daerah-daerah lain, ketokohannya dianggap kontroversial, bahkan sebagian menganggapnya sebagai tokoh opportunistik.

Kesan oportunistik di kalangan masyarakat Sulawesi Selatan itu, didasari pemahaman mereka bahwa dorongan awal terjadinya pemberontakan DI/TII tidak muncul dari kesadaran teologis-politis para

${ }^{24}$ Seperti diceritakan oleh K.H. Latif Amin. Sosok yang menjadi saksi mata selama berlangsungnya gerakan DI/TII itu bertutur bahwa sejak berlangsungnya gerakan DI/TII itu masyarakat memang tidak menaruh simpati karena sepak terjang para pengikutnya yang sering merisaukan penduduk. Karena itu, adanya kebijakan pemerintah untuk menumpas gerakan itu serta merta mendapatkan sambutan dari masyarakat. Salah satu ekspresi sambutan itu adalah dengan jalan memberikan bantuan berupa informasi yang berharga mengenai keberadaan kelompok tersebut serta dengan jalan memutuskan mata rantai sembako, sehingga persediaan pangan gerakan itu menjadi terganggu, meskipun untuk itu masyarakat harus menanggung risiko terjadinya perampokan atas hasil-hasil pangan penduduk. K.H. Latif Amin, Toloh Agama/Ulama, Wawancara, di Bone, 24 Juli 2003. 
Pendekatan Integratif dalam Penegakan Syariat Islam di Sulawesi Selatan

pemimpin dan para pendukungnya. Hal itu tampak bermula dari kebijakan militer pemerintah pusat yang tidak dapat diterima oleh tentara-tentara bekas gerilyawan di daerah ini. Mereka menuntut agar dimasukkan ke dalam suatu blok tertentu dalam barisan tentara nasional yang dibentuk ketika itu dan menginginkan suatu kesatuan militer yang terpisah. Kawilarang, yang saat itu menjabat Komandan Militer untuk wilayah Indonesia Timur menolak permintaan tersebut. Seraya memecat sebagian besar tentaratentara bekas gerilyawan itu, ia hanya menginginkan sedikit yang terpilih di antara mereka untuk dimasukkan ke dalam kesatuan TNI. Qahhar Mudzakkar (yang saat itu berada di Jawa dan merupakan salah seorang pemimpin pasukan gerilyawan yang kharismatik) dipanggil pulang dan diminta untuk menengahi konflik tersebut. Setelah merasa bahwa upayanya tidak membuahkan hasil, ia bahkan bergabung dan memimpin perlawanan bekas gerilyawan di atas. ${ }^{25}$

Selang beberapa waktu kemudian, perlawanan militer ini berubah menjadi pemisahan politik secara terang-terangan dari konsep negara kesatuan sebagaimana didefinisikan pemerintah pusat ketika itu. Baru pada tingkat perlawanan inilah, Qahhar Mudzakar mengontak Kartosuwiryo dan menerima pengangkatannya sebagai "komandan TII untuk wilayah Sulawesi Selatan," dan menjadi "bagian dari NII-nya Kartosuwiryo di Jawa Barat."26

Peristiwa yang berlangsung selama lima belas tahun itu (dari tahun 1950-1965), ternyata menyisakan kesan yang kurang simpatik di kalangan masyarakat. Perilaku para pemimpin dan pendukung gerakan DI/TII ketika itu yang tidak jarang melakukan tindakan kejahatan terhadap jiwa dan harta benda maupun kehormatan, dirasakan masyarakat sangat kontradiktif dengan jargon perjuangannya yakni keinginan untuk mendirikan negara Islam dengan pemberlakuan syariat Islam di dalamnya.

\section{Pendekatan Kultural dalam Penegkan Syariat Islam di Sulawesi Selatan}

Terlepas dari gambaran umum tentang kurangnya apresiasi yang memadai terhadap gagasan seperti itu serta isu-isu yang menyertainya,

${ }^{25}$ Deskripsi saling melengkapi tentang Pemberontakan DI/TII di Sulawesi Selatan, lihat misalnya, B. J Boland, "The Struggle of Islam in Modern Indonesia," terj. Safroeddin Bahar, Pergumulan Islam di Indonesia (Jakarta: Graffiti Press, 1985), 58; Anhar Gonggong, Abdul Qahhar Mudzakkar, 57.

${ }^{26}$ Lihat B. J Boland, “The Struggle of Islam in Modern Indonesia, 59. 
tampak secara jelas bahwa memang telah terjadi perubahan pemikiran di kalangan umat Islam Sulawesi Selatan untuk tidak lagi serta merta mendukung gagasan atas nama agama tanpa aksi-aksi nyata yang dirasakan langsung bermanfaat bagi mereka. Kemenangan Golkar dalam setiap pemilu di daerah ini yang sebelumnya menjadi pendukung-pendukung konvensional partai-partai Islam, dapat dijadikan alasan untuk menguatkan kesimpulan bahwa telah terjadi pergeseran dan perubahan ideologis yang intensif dan mencolok di kalangan umat Islam di daerah ini. Pilihan pada Golkar itu, secara jelas didasari kenyataan bahwa partai inilah yang menurut mereka pada masanya, memiliki segala persyaratan yang dibutuhkan bagi upaya perbaikan kesejahteraan hidup. Meskipun demikian, itu bukan berarti bahwa Islam politik telah lenyap sama sekali. Meskipun telah merosot, ia tetap mempunyai pendukung fanatis di kalangan umat Islam tertentu, terutama kelompok yang mempunyai ikatan-ikatan primordial terhadap kepemimpinan politik Islam yang lama.

Karena pengalaman-pengalaman masa lalu itulah, maka pemikir dan aktivis Islam di daerah ini menyadari perlunya suatu pendekatan dan modus pemikiran maupun aksi baru guna membangkitkan kembali potensi umat Islam. Orientasi kepada politik praktis mulai dikesampingkan sebagai refleksi terhadap perkembangan-perkembangan baru yang harus diresponss secara lebih cerdas dan realistis. Organisasi-organisasi kemasyarakatan seperti NU, Muhammadiyah, DDI, IMMIM dan sebagainya di daerah ini mulai melakukan reorientasi. Mereka sadar bahwa watak birokrasi pemerintah ketika itu -yang masih dipengaruhi mitos pembangkangan atau oposisionalisme Islam,- lebih cenderung mengakomodasi cita-cita nonpolitik Islam. Karena itu, sebagai gantinya, mereka melakukan apa yang oleh Bassam Tibbi disebut revitalisasi kultural (cultural revitalization), ${ }^{27}$ yakni suatu usaha memperkuat kembali dimensi dan wajah kultural Islam dalam rangka meningkatkan potensi dan kualitas umat serta menarik simpati dan responssi dari pemerintah. Revitalisasi kultural ini pada akhirnya bermuara pada munculnya Islam kultural, yakni tampilnya Islam sebagai sumber etik dan moral serta landasan kultural dalam kehidupan berbangsa. Bentuk riil dari upaya menampilkan Islam kultural itu, dapat dilihat dari kegairahan untuk mengartikulasikan prinsip-prinsip Islam (Islamic injunctions) guna

${ }^{27}$ Bassam Tibi, "The Crisis of Modern Islam," sebagaimana dikutip M. Syafii Anwar, Pemikiran dan Aksi Islam: Sebuah Kajian Politik Tentang Cendikiawan Muslim Orde Baru(Cet. I; Jakarta: Paramadina, 1995), 133. 
Pendekatan Integratif dalam Penegakan Syariat Islam di Sulawesi Selatan

dikontribusikan ke dalam proses pembangunan yang sedang berlangsung, di samping upaya-upaya dalam bidang pendidikan dan sosial ekonomi dalam rangka meningkatkan kualitas hidup umat Islam. ${ }^{28}$

Adapun pendekatan kultural lebih menekankan pada penyadaran setiap individu dalam pelaksanaan syariat Islam. Jika setiap umat Islam sudah sadar untuk menjalankan ajaran agamanya, maka dengan sendirinya akan terbentuk masyarakat Islam. Tetapi kelemahan pendekatan ini adalah akan memakan proses waktu yang lebih panjang. Kelemahan tersebut akan semakin tampak jika diukur dari seberapa banyak hukum Islam itu sudah dipositifkan menjadi hukum yang mengikat masyarakat secara tertulis.

Pendekatan kultural juga berarti bahwa dalam penerapan syariat Islam perlu diperhatikan kultur yang terdapat dalam masyarakat. Pengertian ini juga digunakan para pembawa Islam yang pertama di Sulawesi Selatan. Justru melalui pendekatan ini penerapan syariat Islam lebih mudah diterima, karena lebih akomodatif terhadap adat istiadat yang terdapat dalam masyarakat. Pendekatan kultural dengan tidak merombak pranata adat yang telah ada, menyebabkan syariat Islam lebih mudah diterima. Pertentangan antara sarak dengan adat dengan mudah dapat dihindari, seperti tercermin dalam Piagam Sarak yang dibuat oleh Datuk ri Bandang ketika bertugas di Kerajaan Wajo. Dalam lontara disebutkan:

Assiturusenna adek e sarak e

Mappakarajai sarak e ri adak e

Mappakalebbii adak e ri sarak e

Temmakulle sirusak bicara

Narekkopusa i bicaranna adek e

Makkutana i ri sarak e

Narekkopusa i bicaranna sarak e

Makkutanai ri adek e

Temmakkulleni si apusang.

Persetujuan antara adat dan sarak

Sarak menghormati adat

Adat memuliakan sarak

Adat dan sarak tidak saling membatalkan putusan

Kalau adat tidak dapat memutuskan suatu perkara

Adat bertanya pada sarak

${ }^{28}$ Syafii Anwar, Pemikiran dan Aksi Islam, 133.

http://journal.iaingorontalo.ac.id/index.php/am 


\section{Ahmad Faisal}

Kalau sarak tidak dapat memutuskan suatu perkara

Sarak bertanya kepada adat

Keduanya tidak akan keliru dalam mengambil keputusan. ${ }^{29}$

Keberhasilan Datuk ri Bandang meletakkan dasar pembinaan yang kukuh antara kedua pranata tersebut merupakan sebagian dari jasa monumental Datuk ri Bandang, sehingga dalam perkembangan selanjutnya terbuka peluang untuk mensosialisasikan ajaran Islam ke dalam kehidupan bermasyarakat. Sarak pada akhirnya terintegrasi dalam sistem Pangngaderreng yang berfungsi memberi pedoman dan nilai-nilai Islam. Dalam perkembangan selanjutnya, menurut analisa Mattulada, tidak ditemukan lagi pertentangan antara kedua pranata tersebut. Keduanya hidup berdampingan dan saling melengkapi sebagai institusi resmi kerajaan. ${ }^{30}$ Ketaatan rakyat kepada sarak sama dengan ketaatan mereka kepada aspek Pangngaderreng lainnya. Jika terdapat pertentangan antara adat dan sarak, diusahakan agar terjadi kompromi, sebab dalam masalah sosial kemasyarakatan, Islam memiliki daya akomodasi yang kuat. Kecuali itu, jika masih belum ditemukan cara penyelesaian kompromi, maka keput usan akhir diambil dari sarak, sebagaimana dikemukakan oleh Umar Syihab:

Narekko moloiko roppo-roppo, namutabbuttu lesuko ri ade'e

Narekkotabbuttu mupo lesuko ri sara'e, nasaba apettunnna sarae pettung Puang.

Jika engkau menghadapi permasalahan, kemudian langkahmu tertumbuk [tidak menemukan solusi, pen.] maka berpeganglah pada adat. Jika masih menemui jalan buntu, maka berpeganglah pada syara', karena keputusan syara' adalah keputusan Tuhan). ${ }^{31}$

Kalau kenyataan sejarah tersebut mau ditafsirkan, maka keinginan penegakan syariat Islam semestinya berupaya untuk memadukan kedua pendekatan tersebut. Sudah tiba saatnya mengakhiri polemik antara pendekatan struktural dan kultural. Sebab dalam sejarah penerapan syariat Islam di Sulawesi Selatan keduanya digunakan. Mana yang didahulukan tergantung pada problema dan tantangan yang dihadapi. Dalam menghadapi

\footnotetext{
${ }^{29}$ Mattulada, Latoa: Suatu Lukisan Analisis terhadap Antropologi Politik Orang Bugis (Yogyakarta: Universitas Gadjah Mada Press, 1985), 155.

${ }^{30}$ Mattulada, Latoa: Suatu Lukisan, 382.

${ }^{31}$ Umar Syihab, "Hukum Kewarisan Islam dan Pelaksanaannya di Wajo," Disertasi, (Ujungpandang: Universitas Hasanuddin, 1988), 6.
} 
Pendekatan Integratif dalam Penegakan Syariat Islam di Sulawesi Selatan

tantangan yang semakin kompleks masa kini, maka kedua pendekatan itu hendaknya diintegralkan.

Integrasi kedua pendekatan tersebut dapat pula ditafsirkan bahwa upaya penegakan syariat Islam tidak mesti dilakukan dengan menunggu adanya payung hukum berupa otonomi khusus seperti halnya Propinsi Nangroe Aceh Darussalam (NAD), tetapi juga dapat ditempuh melalui jalur Peraturan-Peraturan Daerah (Perda) yang krannya telah dibuka dengan adanya Undang-Undang No. 22/1999 tentang Otonomi Daerah. Lebih dari itu, dengan mengingat Garis-Garis Besar Haluan Daerah Sulawesi Selatan yang menetapkan visi pembangunannya dengan slogan "terwujudnya Sulawesi Selatan menjadi wilayah terkemuka di Indonesia melalui pendekatan kemandirian lokal yang bernafaskan keagamaan,"32 maka peluang bagi usaha memperjuangkan penegakan syariat Islam dalam pengertian inklusif telah mendapatkan lampu hijau.

Di beberapa daerah, bahkan telah diterbitkan perda-perda yang secara langsung mencerminkan semangat ajaran Islam. Di Pinrang misalnya, telah diundangkan perda tentang larangan memperjualbelikan minuman keras, prostitusi dan sejumlah bentuk kejahatan lainnya yang bertentangan dengan agama. Bahkan telah pula diperdakan kewajiban bagi anak didik untuk tahu baca tulis al-Qur'an sebagai syarat melanjutkan studi ke jenjang menengah pertama, serta kebijakan pemda setempat untuk menggaji para imam, guru-guru mengaji dan sebagainya. Daerah-daerah lainnya di Sulawesi Selatan tampaknya juga terdorong untuk mendukung kebijakan GBHD tersebut, seperti halnya Bulukumba, Maros, Gowa dan lain-lain. Karena itu, selalu terbuka kesempatan bagi umat Islam untuk menegakkan syariatnya lewat jalur-jalur konstitusional yang memang dimungkinkan, tanpa harus mereduksi perjuangan penegakan syariat itu pada wilayahwilayah yang justru menimbulkan kontroversi dan bersifat kontra produktif.

\section{Penutup}

Dengan mempertimbangkan aktiva dan passiva masing-masing pendekatan, perdebatan tentang struktural dan kultural sudah saatnya ditelaah ulang. Dialektika kedua pendekatan itu sejatinya merupakan

${ }^{32}$ Lihat Garis-Garis Besar Haluan Daerah Sulawesi Selatan [GBHD] (Makassar: Balai Penelitian dan Pengembangan Daerah [Balitbangda], (Makassar: Dokumentasi Pemda Propinsi, tidak diterbitkan, 2000). 


\section{Ahmad Faisal}

dialektika antara dua gagasan yang sama-sama tidak sempurna, tidak integral dan tidak konprehensif. Karena itu, keduanya semestinya diintegrasikan sebagai satu strategi yang utuh.

Persoalannya, baik Islam kultural yang substansialistik dan lebih menekankan aspek etik maupun Islam struktural yang bersifat legalistik formalistik, sama-sama memiliki kelemahan. Islam formalis, dengan pilihan pada jalur struktural, terbukti tidak sepenuhnya berhasil merealisasikan citacita penegakan syariat Islam. Alih-alih berhasil menegakkan ideologi Islam beserta perangkat-perangkat sosio-ekonomi-politiknya (baca: syariat Islam), sekedar representasi dan akomodasi kalangan Islam dalam negara pun sulit terealisasikan.

Sebaliknya, Islam kultural pun-meski selama ini dianggap berhasil melahirkan pembesaran kelas menengah Muslim dan memaksa negara untuk memberi ruang akomodasi dan representasi yang lebih baik bagi kalangan Islam-, juga gagal memberdayakan umat secara politik, khususnya di level bawah. Para elit agama, cendikiawan dan kalangan LSM misalnya (terlepas dari adanya depolitisasi negara) selama bertahun-tahun tidak cukup mampu mengubah massa mengambang (floating mass) menjadi massa kalkulatif dan rasional yang memiliki tingkat kesadaran keagamaan yang signifikan. Lebih dari itu, Islam kultural juga tidak berdaya dalam mencegah terjadinya "kriminalisasi politik" seperti halnya Korupsi, Kolusi dan Nepotisme (KKN) dan berbagai kezaliman politik lainnya yang dilakukan para pejabat yang notebene mayoritas Muslim, bahkan diantaranya banyak yang bertitel haji. Hal itu justru terjadi di tengah klaim keberhasilan kalangan Islam kultural dan pada kurun waktu yang oleh banyak kalangan disebut sebagai masa akomodasi timbal balik (mutual acomodation). Dengan melihat alasan sosiopolitis di atas, maka sangat argumentatif jika kedua kutub pendekatan yang selama ini diposisikan secara dikotomis, diintegralkan.

\section{Daftar Pustaka}

Anshari, Endang Saefuddin. The Jakarta Charter1945: The Struggle for an Islamic Constitution in Indonesia. Kualalumpur: Muslim Youth Movement of Malaysia, 1979.

Anwar, M. Syafii. Pemikiran dan Aksi Islam: Sebuah Kajian Politik Tentang Cendikiawan Muslim Orde Baru. Cet. I; Jakarta: Paramadina, 1995. 
Pendekatan Integratif dalam Penegakan Syariat Islam di Sulawesi Selatan

Boland, B.J. The Struggle of Islam in Modern Indonesia, The Hague: Martinus Nijhoff, 1971.

Boland, B.J. The Struggle of Islam in Modern Indonesia," Terj. Safroeddin Bahar, Pergumulan Islam di Indonesia. Jakarta: Graffiti Press, 1985.

Effendy, Bahtiar. Islam dan Negara: Transformasi Pemikiran dan Praktik Politik Islam di Indonesia. Jakarta: Paramadina, 1998.

Effendy, Bahtiar. Teologi Baru Politik Islam: Pertautan Agama, Negara dan Demokrasi. Cet. I; Yogyakarta: Galang Press, 2001.

Gonggong, Anhar. Abdul Qahhar Mudzakkar: Dari Patriot hingga Pemberontak. Jakarta: Gramedia Widiasarana Indonesia, 1992.

Hassan, Muhammad Kamal. Muslim Intelectual Responsses to "New Order" Modernization in Indonesia, 1980.

Maarif, Ahmad Syafi'i. Islam dan Masalah Kenegaraan: Studi tentang Percaturan dalam Konstituante. Jakarta: LP3ES, 1985.

Mattulada. Latoa: Suatu Lukisan Analisis terhadap Antropologi Politik Orang Bugis. Yogyakarta: Universitas Gadjah Mada Press, 1985.

Mudzakkar, Abdul Qahhar. Revolusi Ketatanegaraan Indonesia Menudju Persaudaraan Manusia. Makassar: Hasanuddin University Press, 1381 $\mathrm{H}$.

Mudzakkar, Abdul Qahhar. Tjatatan Bathin Pedjoang Islam Revolusioner, Jilid III. Singapura: Qalam Press, $1382 \mathrm{H}$.

Noer, Deliar. Partai Islam di Pentas Nasional 1945-1996. Jakarta: Pustaka Utama Graffiti, 1987.

Pipitseputra. Beberapa Aspek dari Sejarah Indonesia Aliran Nasionalis, Islam, Katolik sampai Akhir Zaman Perbedaan Paham. Ende-Flores: Nusa Indah, 1973.

Syihab, Umar. "Hukum Kewarisan Islam dan Pelaksanaannya di Wajo," Disertasi. Ujungpandang: Universitas Hasanuddin, 1988. 